\title{
Understanding the Relationship between Unemployment and Inflation in Nigeria
}

\author{
Odo Stephen $\mathrm{I}^{1} \quad$ Elom- Obed Favour $\mathrm{O}^{1} \quad$ Okoro Thomas O. ${ }^{1} \quad$ Nwachukwu Johnson $\mathrm{O}^{2}$ \\ 1.Department of Economics, Ebonyi State University, PMB 053, Abakaliki,Ebonyi State, Nigeria \\ 2.Department of Accountancy, Ebonyi State University, PMB 053, Abakaliki,Ebonyi State, Nigeria
}

\begin{abstract}
This study investigated the relationship between unemployment and inflation in Nigeria from 1980-2015. The model specified unemployment as a function of inflation, money supply $\%$ GDP, total government expenditure $\%$ of GDP. The statistical tests used were causality test, VECM test, co integration test. Based on the above tests carried out, the study found out that: (i) Inflation significantly impacted unemployment in Nigeria both in the long run and short run within the period under review.(ii) There exist a significant causal relationship among the variables in the model. Based on the results, the study recommended that government should use discretionary policy that would reduce unemployment by boosting government expenditure and maintain stability in money supply.
\end{abstract}

Keywords: Unemployment, Inflation, Philip's curve, Nigeria, Co integration, Granger causality.

\section{INTRODUCTION}

For many years, Nigeria economy has been facing the crisis of unemployment and inflation management, many economists had been investigating to understand the nature of relationship existing between the concepts of inflation and unemployment. Inflation and unemployment are very crucial issues in any economy as all policymakers would to a large extent; desire to have low rates of inflation and unemployment. Many economists believe that a single-digit rate of inflation and 5\% rate of unemployment are tolerable and may not create macroeconomic instability in an economy all things being equal. Since macroeconomic stability is vital for growth, planning, reduction in poverty and overall development of the economy, the desirability of investigating to understand the movement of economic fundamentals such as inflation and unemployment cannot be overestimated if the goal of stability of the economy would be achieved.

Unemployment is seen as one of the serious impediment to economic advancement; it leads to a waste of manpower resource in the economy and also generates loss of welfare in terms of lower output thereby leading to lower income and well-being. Unemployment is therefore defined as an observable fact that arises when a person who is actively searching for employment and is willing to accept the prevailing wage rate is unable to find work. Unemployment is frequently used as a measurement of economy's health. Unemployment rate is the most repeatedly used measure of unemployment; this is calculated by taking the number of people who are unemployed and dividing them by the number of people who are working (the labor force). Many economists had classified unemployment into many types. The widest two types of unemployment are voluntary and involuntary unemployment. Unemployment is said to be voluntary when the person willingly on his own left job in search of other better jobs and between the periods he/she left the job to the period he would get another job he stays without a job, while involuntary unemployment is a situation where the person had been fired or laid off and now looking for another job. (Orji, Anthony-Orji and Okafor,2015).

Inflation in the other hand is defined as increase in the general price level which continued for long time in an economy; it is also, a constant rise in the price levels of commodities and services, leading to a fall in the currency's purchasing power. Some group of researchers believed that while high inflation is not favourable for an economy because of its adverse effect on economic performance, low inflation is equally harmful because it will lead to eventual stagnation of the economy hence its presence at a mild level is needed for economic growth. The problem of inflation is not confined to national boundaries neither is it restricted to emerging market economies of the world; it is also an over-arching challenge in the developed market economies, since it is by no means a new challenge or phenomenon, as over the years, its control has become the unquestioned mantra of economic policymakers worldwide. Previous administration in Nigeria had made several efforts in managing both inflation and unemployment issues. For instance the National Economic Empowerment and Development Strategy (NEEDS) as introduced by the federal government was targeted at lowering inflation rate in Nigeria, making jobs available to many unemployed Nigeria people among other things. In spite of all these policies, unemployment and inflation pressures have continued to be on the increase. (Omoke, 2010).

From theoretical and empirical studies, several factors have been adjudged to influence either rise in prices or rate in unemployment. Such factors includes, government expenditure, money supply, interest rate, etc, these factors could enhance or mar the growth of the economy. While researchers are in consensus on the effect of these factors on inflation or unemployment, the direction of the nature of this influence is yet a subject of debate. For example, in the issue of effect of public expenditure on the economy, some economists promotes 
Wagner's view of public expenditure, while others stressed that the Keynesian postulation is prevalent in modern economies. Most of these factors are discussed below.

Total government expenditure refer to the expenses of the government at all level, federal, state and local in the provision of social amenities, welfare services and consumption purposes. It is also government consumption expenditure, investment expenditure, and transfer payments. Government expenditure in national income accounting is classified as follow; the acquisition by governments of goods and services for current use to directly satisfy the individual or collective needs of the community, as government final consumption expenses. Government acquisition of goods and services intended to create future benefits, such as infrastructure investment or research spending, as government investment expenditure (government gross capital formation). These two types of government spending, on final consumption and on gross capital formation, together constitute one of the major components of gross national product and can either be used to create employment or cause inflation.

Money supply is the entire stock of currency and other liquid instruments circulating in a country's economy as of a particular time. Also referred to as money stock, money supply includes safe assets, such as cash, coins, and balances held in checking and savings accounts that businesses and individuals can use to make payments or hold as short-term investments. It can be classified into M0, M1, M2 and M3 according to the type and size of the account in which the instrument is kept. M0 and M1, for example, are also called narrow money and they include coins and notes that are in circulation and other money equivalents that can be converted easily to cash. M2 includes M1 and, in addition, short-term time deposits in banks and certain money market funds. M3 includes M2 in addition to long-term deposits. An increase in the supply of money typically lowers interest rates, which in turns generates more investment and puts more money in the hands of consumers; thereby stimulating spending and also the increase in the amount of money in circulation would lead to rise in the prices of goods and service (inflation). Businesses respond by ordering more raw materials and increasing production. The increased business activity raises the demand for labor. The opposite can occur if the money supply falls or when its growth rate decline.

Economic growth is regarded as increase in the final goods and services produced in the country in a particular year. Economic growth rate is a measure of economic growth from one period to another in percentage terms. This measure does not adjust for inflation; it is expressed in nominal terms. In practice, it is a measure of the rate of change in nation's gross domestic product (GDP) from one year to another, but gross national product (GNP) can also be used if a nation's economy depends heavily on foreign earning. It provides an insight into the general direction and magnitude of overall economy. Inflation of double digit is seen to contribute negatively to economic growth while increase in unemployment reduces the productive capacity of the country.

\section{Statement of Problem}

The increasing nature of unemployment and inflation in Nigeria is quite worrisome, a situation where there is high unemployment and high inflation at the same time and even low growth (stagflation), these point out that there is insufficient macroeconomic performance in the economy. The combined effect of rising prices, higher unemployment, higher taxes and slower growth in real income produced the dissatisfaction that makes "stagflation" a widely discussed problem. Governments appear unable to reduce inflation without increasing unemployment or to reduce unemployment without, sooner or later, increasing inflation. The appearance of a positive relation between the cyclical average rate of unemployment and the cyclical average rate of price change is misleading. Therefore this research work is set out to examine the relationship of unemployment and inflation in order to understand the direction of the causality, know the reason for or against Philip curve which posits that a trade-off between employment and inflation exist and suggest to the government the way out of the situation. The trend of unemployment and inflation are explained below to observe the nature of the trade-off between unemployment and inflation.

Table 1 for Unemployment and Inflation

\begin{tabular}{|l|l|l|}
\hline Year & Unemployment & Inflation \\
\hline 1980 & 9.9 & 6.4 \\
\hline 1985 & 5.5 & 6.1 \\
\hline 1990 & 7.5 & 6.1 \\
\hline 1995 & 72.8 & 1.9 \\
\hline 2000 & 6.9 & 18.1 \\
\hline 2005 & 17.9 & 11.9 \\
\hline 2010 & 13 & 21.1 \\
\hline 2015 & 11.68 & 8.2 \\
\hline
\end{tabular}




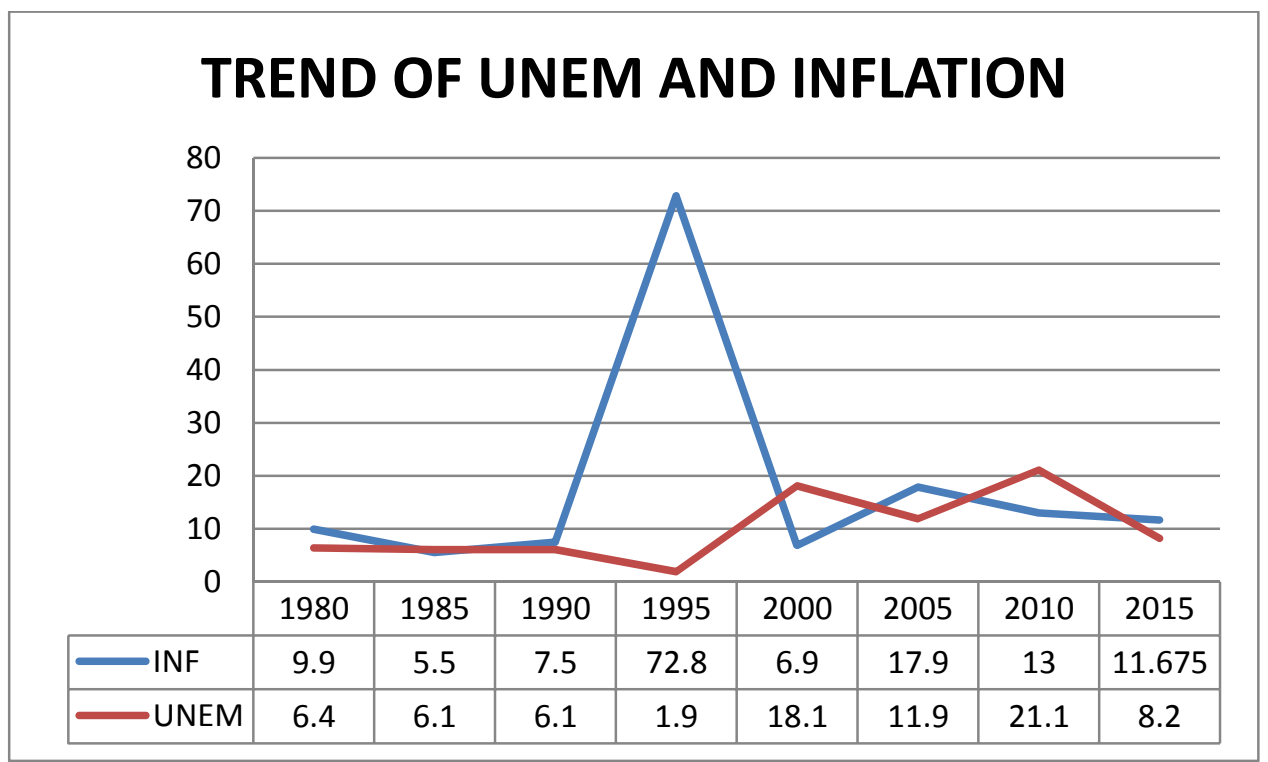

From the graph of unemployment and inflation above 1980 inflation was 9.9 and unemployment was 6.4, in the year 1985,1995 and 2015 there were decrease in both unemployment and inflation, in 1990 inflation increased but unemployment remained unchanged, during the period of 2000 and 2010 inflation decreased while unemployment increased. Following the inconsistence in the trend of unemployment and inflation, this study investigated the reason for the fluctuations.

\section{Statement of Research Questions}

In order to find solution to the problem which this research work identified the following research question are raised

(i) does inflation impact unemployment in Nigeria?

(ii) is there any significant casual relationship existing between the explanatory variables and unemployment in Nigeria?

\section{Objective of the Study}

The overall objective of this study is investigating to understand the casual relationship between unemployment and inflation in Nigeria within the period that this research work is carried out. The specific objectives are

(i) Determine the impact of inflation on unemployment in Nigeria.

(ii) To investigate the degree of significant casual relationship existing between the explanatory variables and unemployment in Nigeria.

\section{Review of Literature \\ Theoretical review \\ The Phillips Curve}

A.W. Phillips who first investigated the relationship between unemployment and the rate of money wages change in the 1861-1957 opined that there is negative relationship amid rate of unemployment and rate of inflation. His analysis was based on the data for United Kingdom; he derived an empirical correction that when unemployment is high, the rate of increase in money wage is low. He further stated that this would happen because workers are reluctant to offer their services at less than the prevailing rates when the demand for labour is low and unemployment is high so that wage rates fall slowly. Also when unemployment is low, the rate of increase in money wage rate is high. He argued that this is because when the demand for labour is high and there are few unemployed, it is expected that the employer would bid wage rates up in order to make the work attractive to the worker and in the period of falling business activities when demand for labour is decreasing and unemployment is increasing, employers would be reluctant to grant wage increase. Rather they would reduce wages, but workers and union would be reluctant to accept wage cut consequently, employers are forced to dismiss workers therefore leading to high rate of unemployment, Ugwuanyi (2004). Below is the graph explaining the inverse relationship between unemployment and inflation (Phillips Curve). 


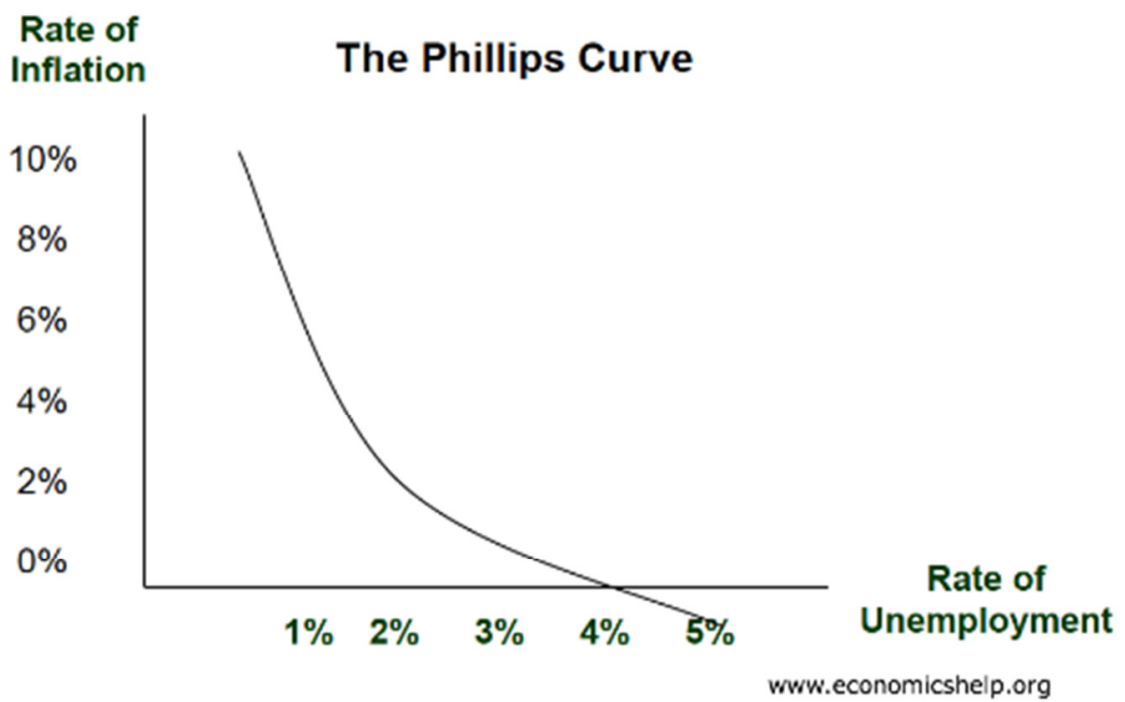

In the above graph, $10 \%$ rise in rate of inflation brought about $1 \%$ fall in the rate of unemployment, an $8 \%$ fall in the rate of inflation lead to $2 \%$ increase in the rate of unemployment etc.

\section{Efficiency-wage models}

The new Keynesian economist who worked with efficiency wage model stated that there is solid macroeconomic reason for inflexible wages. They argued that the firms sometimes find it in their interest to pay wage rates above market - clearing levels because labour productivity depends on the wage rate the firm pays to employees. Therefore a cut in wages could cause the labour productivity to decline, which, in turn raises the firms costs. This model also states that the employee productivity increased when a higher wage paid to them than when lower wage is paid to them. By paying a higher- than- market wage, firms provide an incentive to workers to be productive and do less shirking, among other things, as shirking decline, so do the monitoring (management) cost of the firm decline. Arnold (2004)

\section{Empirical review}

Orji, Anthony-Orji and Okafor (2015) investigated inflation and unemployment nexus in Nigeria by testing if the Original Phillips curve proposition holds for Nigeria. The study adopted a distributed lag model with data covering the period 1970-2011. The consumer's price index (a measure of inflation rate), was regressed on unemployment rate, growth rate of money supply, budget deficit, real gross domestic product, interest rate and the lag of current interest rate. The result reveals that unemployment is a significant determinant of inflation and that there is a positive relationship between inflation and unemployment rate in Nigeria. This finding invalidates the original proposition on the Phillips curve hypothesis in Nigeria. The study therefore recommends that the economy should be diversified and appropriate policies should be put in place by Government and the monetary authorities in order to curb the menace of inflation and unemployment and consequently reduce the problem of stagflation in Nigeria. Again, there is a need for strong institutional collaboration in dealing with these two macroeconomic variables; unemployment and inflation as have been recommended in the paper.

Eze, Apeh and Eze (2015) observed the relative impact of inflation and unemployment on the level of economic activities in Nigeria. Granger Causality test was used to determine the existence of any causal influence between inflation and unemployment. The study indicated that both inflation and unemployment significantly affect the level of Nigeria's economic performance, and that causality runs from inflation to unemployment. The results also revealed that the two variables are inversely related to economic growth both in the short-run and long-run. And the study concludes that inflation and unemployment are inversely related to each other in the short-run but positively related in the long-run. The study therefore recommends that the Central Bank of Nigeria's (CBN) should continuous pursuit, vigorously and transparently, the policy of inflation targeting, improvement of infrastructure and access to credit to make it possible for more people to do business in Nigeria. Also that a partnership between the Ministry of Trade and Investment and the World Bank in the formers drive towards increasing foreign direct Investment inflow, job creation, and generation of policies towards the growth of small and medium enterprises (SMEs).

Umaru and Zubairu (2012) investigated the relationship between unemployment and inflation in the Nigerian economy from 1977 - 2009. They used the following pre- test Augmented Dickey-Fuller unit root to test the stationarity of all the variables, cointegration test was conducted through the application of Johansen cointegration technique to examine the long-run relationship between the two phenomenon after which Granger 
causality test was conducted to determine causation between unemployment and inflation, then, lastly $\mathrm{ARCH}$ and GARCH technique was conducted to determine the existence of volatility in the series. The results indicated that inflation impacted negatively on unemployment. The causality test revealed that there is no causation between unemployment and inflation in Nigeria during the period of study and a long-run relationship exists between them as confirmed by the co integration test. ARCH and GARCH results showed that the time series data for the period under review exhibit a high volatility clustering. Therefore the study recommended the use of inflation/unemployment theory that is drawn from data sourced within the country and also improvement in the existing theories in order to ensure their applicability in the Nigerian context, so as to achieve a desire reduction in unemployment and inflation which in turn boost economic growth and development.

Al-Zeaud (2014) studied the existence of trade-off relationship between unemployment and inflation in the Jordanian economy between 1984 and 2011. Granger-causality was used to test casual relationship between variables and the direction of causation. The following techniques were also adopted unit root test, co-integration to test for Stationary and co-integration of the variables. The study indicated no causal relationship between unemployment and inflation in Jordan during the study period which means there is no trade-off relationship between the two variables. The study recommended that policy makers should pay attention to these findings when they tackle unemployment issue, and encourages them to conduct programs to reduce unemployment rate through creation of productive and labor-intensive projects, also replace foreign labor with local labor, while continuing to control inflation, to ensure that Jordan accomplish a desired rate of unemployment and inflation, which in turn hearten economic growth.

Ademola and Badiru (2016) examined the effects of unemployment and inflation on economic performance in Nigeria. Ordinary Least Square (OLS) technique was adopted with various diagnostic tests to determine how fit are the data for the analysis. The study indicated that there exist long-run relationship between RGDP, Unemployment and inflation. The results also showed that unemployment and inflation are positively related to economic growth not response as expected to growth of output in the country.

Torruam and $\mathrm{Abu}$ (2014) examined the causal relationship between unemployment, inflation and crime in Nigeria for the period 1980-2011. The following tests were carried out: unit root test cointegration test which was used to test for stationarity the long-run relationship among the variables respectively. Granger-causality suggested that there is unidirectional causality running from unemployment and inflation to crime in Nigeria. The study recommended that holistic effort should be made by governments at all levels to create jobs and arrest unemployment. Nigerian government instead of employing foreigners should sponsor her citizens abroad for studies in diverse fields of study.

Muhammad (2014) investigated the impact of inflation and unemployment on economic growth in Pakistan. The time series data used for the time period of 1980 to 2010 which is collected from world data bank. The unit root ADF and Philip perron showed that economic growth is stationary at level as well as $1^{\text {st }}$ difference but unemployment and inflation are stationary at $1^{\text {st }}$ difference. The ARDL result indicated that there is a long run relationship between the variable. Furthermore, the results of White Heteroskedasticity, Ramsey reset and Breusch-Godfrey Serial Correlation LM test showed that there is no problem of heteroskedasticity, misspecification of model and serial correlation respectively.

Mohammed, Okoroafor and Awe (2015) analyzed the relationship between unemployment, inflation and economic growth in Nigeria from 1987-2012. The study utilizes secondary data to analyze the relationship between unemployment, inflation and economic growth. The methodology used for the study was ordinary least squares. The results confirms that in the long run, interest rate and total public expenditure have significant impact on economic growth in Nigeria, while inflation and unemployment has inverse effects on growth in Nigeria. The possible justification for the inverse effect of inflation on price level is that inflation may not be due to aggregate demand pressure but rather due to hiccups in the supply chain of goods both from the domestic and foreign supply outlets. Empirical deductions also signify the presence of significant feedback from the long run to short run disequilibrium. However, there exists a causal linkage between inflation, unemployment and economic growth in Nigeria. In conclusion, the paper recommended that the government must as a matter of necessity to improve or continue to fine-tune macroeconomic policy instruments to achieve a sustainable and enable environment that will enhance increase in domestic output. 
Major Gap in Literature

\begin{tabular}{|c|c|c|c|c|c|}
\hline Author & Topic & Methodology & Variables used & Findings & Gap \\
\hline $\begin{array}{l}\text { Torruam and } \\
\text { Abu (2014) }\end{array}$ & $\begin{array}{l}\text { the causal } \\
\text { relationship } \\
\text { between } \\
\text { unemployment, } \\
\text { inflation and } \\
\text { crime in Nigeria } \\
\text { for the period } \\
1980-2011\end{array}$ & $\begin{array}{l}\text { Vector } \\
\text { correction } \\
(\mathrm{VECM})\end{array}$ & $\begin{array}{l}\text { Inflation, } \\
\text { unemployment and } \\
\text { gdp }\end{array}$ & $\begin{array}{l}\text { unidirectional } \\
\text { causality running } \\
\text { from } \\
\text { unemployment } \\
\text { and inflation to } \\
\text { crime in Nigeria }\end{array}$ & $\begin{array}{l}\text { The scope of the study } \\
\text { was } 1980-2011 \text { while } \\
\text { the current research } \\
\text { scope is } 1980-2015 \text {. A } \\
\text { four (4) years update. }\end{array}$ \\
\hline $\begin{array}{l}\text { Mohammed, } \\
\text { Okoroafor \& } \\
\text { Awe (2015) }\end{array}$ & $\begin{array}{l}\text { the relationship } \\
\text { between } \\
\text { unemployment, } \\
\text { inflation and } \\
\text { economic } \\
\text { growth in } \\
\text { Nigeria }\end{array}$ & $\begin{array}{l}\text { ordinary least } \\
\text { squares (OLS) }\end{array}$ & $\begin{array}{l}\text { Inflation, } \\
\text { unemployment, } \\
\text { interest rate and } \\
\text { total government } \\
\text { expenditure. }\end{array}$ & $\begin{array}{l}\text { Interest rate and } \\
\text { total public } \\
\text { expenditure have } \\
\text { significant } \\
\text { impact on } \\
\text { economic growth } \\
\text { in Nigeria, while } \\
\text { inflation and } \\
\text { unemployment } \\
\text { has inverse } \\
\text { effects on growth } \\
\text { in Nigeria. }\end{array}$ & $\begin{array}{l}\text { The study used OLS } \\
\text { while the current study } \\
\text { used VECM the scope } \\
\text { of the study also was } \\
1980-2012 \text { while the } \\
\text { current study did three } \\
\text { year update i.e 1980- } \\
2015\end{array}$ \\
\hline $\begin{array}{l}\text { Muhammad } \\
(2014)\end{array}$ & $\begin{array}{l}\text { the impact of } \\
\text { inflation and } \\
\text { unemployment } \\
\text { on economic } \\
\text { growth in } \\
\text { Pakistan. }\end{array}$ & $\begin{array}{l}\text { Auto regressive } \\
\text { distributed lag } \\
\text { model (ARDL). }\end{array}$ & $\begin{array}{l}\text { Inflation, } \\
\text { unemployment and } \\
\text { GDP }\end{array}$ & $\begin{array}{l}\text { The ARDL result } \\
\text { indicated that } \\
\text { there is a long } \\
\text { run relationship } \\
\text { between the } \\
\text { variable. }\end{array}$ & $\begin{array}{lrr}\text { The research } & \text { used } \\
\text { ARDL } & \text { while } & \text { the } \\
\text { current } & \text { study } & \text { used } \\
\text { VECM } & & \end{array}$ \\
\hline $\begin{array}{l}\text { Ademola and } \\
\text { Badiru } \\
(2016)\end{array}$ & $\begin{array}{l}\text { The effects of } \\
\text { unemployment } \\
\text { and inflation on } \\
\text { economic } \\
\text { performance in } \\
\text { Nigeria. }\end{array}$ & $\begin{array}{lr}\text { Ordinary } & \text { Least } \\
\text { Square } & \text { (OLS) } \\
\text { technique } & \end{array}$ & $\begin{array}{l}\text { RGDP, } \\
\text { Unemployment and } \\
\text { inflation. }\end{array}$ & $\begin{array}{l}\text { Study showed } \\
\text { that } \\
\text { unemployment } \\
\text { and inflation are } \\
\text { positively related } \\
\text { to economic } \\
\text { growth. }\end{array}$ & $\begin{array}{l}\text { The study used OLS } \\
\text { while current study } \\
\text { used VECM and also } \\
\text { that the study variables } \\
\text { are different from the } \\
\text { current study variable } \\
\text { such as money supply, } \\
\text { total government } \\
\text { expenditure }\end{array}$ \\
\hline
\end{tabular}

\section{METHODOLOGY}

\section{Research design}

This study used ex-post factor research design, this is because the data used already exist and cannot be manipulated.

\section{Model Specification}

The research is anchored on the Phillips Curve which stated that the relationship between inflation and unemployment with relation to the short-run aggregate supply curve is an inverse one. He argued that when the economy moves up to the SAS curve toward a higher price level and a higher output this reduces unemployment. Nevertheless, since there is a higher price level, this increases inflation. Thus, in order to get lower unemployment rates, a rise in inflation must be sacrificed. The Phillips Curve is made up of an equation with several parts such as presented below

$$
\pi=\pi \mathrm{e}-\beta\left(\mathrm{u}-\mathrm{u}^{\mathrm{r}}\right)+\nu
$$

In other to establish the influence of inflation on unemployment, equation is transposed thus;

$$
\left(\mathrm{u}-\mathrm{u}^{i}\right)=\pi \mathrm{e}-\pi+v
$$

Where: $\pi=$ Inflation, $\pi \mathrm{e}=$ Expected Inflation, $\beta$ is a parameter that measures the response of inflation with relation to cyclical unemployment, $\left(\mathrm{u}-\mathrm{u}^{\mathrm{r}} \mathrm{)}\right)=$ Cyclical Unemployment and $=$ Supply Shocks.

To accommodate the variables used in this study the equation two (2) is stated functionally as

$\mathrm{UNEM}=\mathrm{f}(\mathrm{INF}, \mathrm{M} 2 \mathrm{GDP}, \mathrm{TGEXGDP}$,

Where, UNEM = Unemployment, INF = Inflation, M2GDP = Money supply $\%$ of GDP, TGEXGDP = Total government expenditure \% of GDP.

Equation 3 is presented in a linear form for estimation as follows;

$\mathrm{UNEM}_{\mathrm{t}}=\beta_{0}+\beta_{1} \mathrm{INF}_{\mathrm{t}-1}+\beta_{2} \mathrm{M}_{2} \mathrm{GDP}_{\mathrm{t}-1}+\beta_{3} \mathrm{TGEXGDP}_{\mathrm{t}-1}+\mu_{\mathrm{t}}$ 
Where, UNEM, INF, M2GDP, TGEXGDP, are as explained above; $\beta_{0}=$ Constant term, $\beta_{1-} \beta_{3}=$ Regression coefficients of both dependent and independent variables specified; $\mu_{\mathrm{t}}=$ Error Term

\section{Data Discussion}

In this study all the variables specified are hereby discussed below:

Unemployment (UNEM) is defined as an observable fact that arises when a person who is actively searching for employment and is willing to accept the prevailing wage rate is unable to find work. Unemployment is frequently used as a measurement economy's health. unemployment rate is the most repeatedly measure of unemployment, this is calculated by taking the number of people who are unemployed and divide them by the number of people who working (in the labor force).

Inflation (INF) in the other hand is defined as increase in the general price level which continued for long time in an economy; it is also, a constant rise in the price levels of commodities and services, leading to a fall in the currency's purchasing power. Inflation is calculated by individual prices of commodity divided by the base year, multiplied by 100 .

Money Supply (M2\%GDP) Money supply is the entire stock of currency and other liquid instruments circulating in a country's economy at a particular time. Also referred to as money stock, money supply includes safe assets, such as cash, coins, and balances held in checking and savings accounts that businesses and individuals can use to make payments or hold as short-term investments. M2, M2\%GDP include coins and notes that are in circulation and other money equivalents that can be converted easily to cash and in addition, shortterm time deposits in banks and certain money market fund. This is calculated as percentage of the productivity of the economy.

Total government expenditure(TGEXGDP) is refer to the expenses of the government at all level federal, state and local in the provision of social amenities, welfare services and consumption purposes. It is also government consumption expenditure, investment expenditure, and transfer payments calculated as percentage of the productivity of the economy.

\section{Sources of data employed}

The data used for this study covered 1980 to 2015 and were sourced from central bank of Nigeria statistical bulletin (2012 and 2015).

\section{Estimation Procedure}

The following pre test are used: unit root test which was used to test for the stationarity of the variables, Johansen Co integration test statistics also was used to ascertain if there are any co- integrating vector. VECM and Granger causality test statistic were used as econometric method of analyses.

\section{RESULTS}

Unit Root Test

Table 2: Augmented Dickey Fuller Unit Root Test

Trend and Intercept (Series at Level)

\begin{tabular}{|l|l|l|l|l|}
\hline Series & ADF Test Statistics & $\begin{array}{l}5 \% \\
\text { Critical values }\end{array}$ & Pval & Remarks \\
\hline UNEM & -2.311173 & -3.544284 & 0.4173 & Not Stationary \\
\hline INF & -3.122014 & -3.544284 & 0.1171 & Not Stationary \\
\hline M2 GDP & -2.727732 & -3.544284 & 0.2323 & Not Stationary \\
\hline TGEXGDP & -1.134685 & -3.544284 & 0.9083 & Not Stationary \\
\hline
\end{tabular}

Sources: Researcher's compilation from E-views 9

Table 3: Augmented Dickey Fuller Unit Root Test

Trend and Intercept (Series at $1^{\text {st }}$ difference)

\begin{tabular}{|l|l|l|l|l|}
\hline Series & ADF Test Statistics & $\begin{array}{l}5 \% \\
\text { Critical values }\end{array}$ & Pval. & Remarks \\
\hline UNEM & -5.458513 & -3.548490 & 0.0005 & Stationary \\
\hline INF & -5.657072 & -3.548490 & 0.0003 & Stationary \\
\hline M2 GDP & -5.172314 & -3.548490 & 0.0010 & Stationary \\
\hline TGEXGDP & -6.132240 & -3.548490 & 0.0001 & Stationary \\
\hline
\end{tabular}

Sources: Researcher's compilation from E-views 9 
Table 4: Phillips Perron Unit Root Test

Trend and Intercept (Series at Level)

\begin{tabular}{|l|l|l|l|l|}
\hline Series & PP Test Statistics & $\begin{array}{l}5 \% \\
\text { Critical values }\end{array}$ & Pval. & Remarks \\
\hline UNEM & -2.311173 & -3.544284 & 0.4173 & Not Stationary \\
\hline INF & -3.010107 & -3.544284 & 0.1439 & Not Stationary \\
\hline M2 GDP & -2.511886 & -3.544284 & 0.3208 & Not Stationary \\
\hline TGEXGDP & -1.185573 & -3.544284 & 0.8981 & Not Stationary \\
\hline
\end{tabular}

Sources: Researcher's compilation from E-views 9

Table 5: Phillips Perron Unit Root Test

Trend and Intercept (Series at $1^{\text {st }}$ Difference)

\begin{tabular}{|l|l|l|l|l|}
\hline Series & PP Test Statistics & $\begin{array}{l}5 \% \\
\text { Critical values }\end{array}$ & Pval. & Remarks \\
\hline UNEM & -5.440370 & -3548490 & 0.0005 & Stationary \\
\hline INF & -11.19917 & -3548490 & 0.0000 & Stationary \\
\hline M2 GDP & -7.179917 & -3548490 & 0.0000 & Stationary \\
\hline TGEXGDP & -6.298888 & -3548490 & 0.0000 & Stationary \\
\hline
\end{tabular}

Sources: Researcher's compilation from E-views 9

Table 6: Unrestricted Cointegration Rank Test (Trace)

\begin{tabular}{|l|l|l|l|l|}
\hline $\begin{array}{l}\text { Hypothesized No.of } \\
\text { CE }(\mathrm{s})\end{array}$ & Eigenvalue & Trace statistics & $\begin{array}{c}\text { 0.05 } \\
\text { Critical value }\end{array}$ & Prob** \\
\hline None $*$ & 0.657529 & 57.72347 & 47.85613 & 0.0045 \\
\hline At most 1 & 0.308891 & 21.29019 & 29.79707 & 0.3398 \\
\hline At most 2 & 0.217814 & 8.728621 & 15.49471 & 0.3911 \\
\hline At most 3 & 0.011000 & 0.376078 & 3.841466 & 0.5397 \\
\hline
\end{tabular}

Sources: Researcher's compilation from E-views 9

Trace test indicates 1 cointegrating eqn (s) at the 0.05 level.

Vector Error Correction Estimates (Long-Run Result)

The vector error correction result (upper chamber) depicting the long run relationship of inflation and unemployment, also represented by the normalized co integrating equation as;

$\mathrm{UNEM}=-23.99+0.281978 \mathrm{INF}+0.309896 \mathrm{M} 2 \mathrm{GDP}+0.001204 \mathrm{TGEXGDP}$

Table 7: System Equation (Vector Error Correction Estimates Short-Run Result)

\begin{tabular}{|l|l|l|l|l|}
\hline & Coefficient & Std.Error & t-Statistics & Prob \\
\hline ECM (1) & -0.734766 & 0.166314 & -4.417948 & 0.0002 \\
\hline UNEM (-1) & -0.018870 & 0.157128 & -0.120092 & 0.9055 \\
\hline UNEM (-2) & 0.095408 & 0.172337 & 0.553611 & 0.5852 \\
\hline INF (-1) & 0.125763 & 0.048603 & 2.587559 & 0.0165 \\
\hline INF (-2) & 0.090818 & 0.044697 & 2.031862 & 0.0539 \\
\hline M2GDP (-1) & 0.056475 & 0.107114 & 0.527243 & 0.6031 \\
\hline M2GDP (-2) & 0.161082 & 0.112712 & 1.429142 & 0.1664 \\
\hline TGEXGDP (-1) & 0.010857 & 0.003066 & 3.540596 & 0.0017 \\
\hline TGEXGDP (-2) & 0.009146 & 0.003605 & 2.537170 & 0.0184 \\
\hline C (10) & -2.773869 & 0.926588 & -2.993636 & 0.0065 \\
\hline
\end{tabular}

R-squared $=0.531455$, F-statistics $=2.898686, \mathrm{DW}=2.058551$

Source: Researchers' compilation from E-view 9 
Table 8: Pairwise Granger Causality Test Result

\begin{tabular}{|l|l|l|l|}
\hline Null Hypothesis & Obervations & F-Statistics & Prob \\
\hline INF does not Granger Cause UNEM & 34 & 1.29443 & 0.2894 \\
UNEM does not Granger Cause INF & & 1.05022 & 0.3628 \\
\hline M2GDP does not Granger Cause UNEM UNEM does not & 34 & 0.52690 & 0.5960 \\
Granger Cause M2GDP & & 0.03539 & 0.9653 \\
\hline TGEXGDP does not Granger Cause UNEM & 34 & 3.83090 & 0.0334 \\
UNEM does not Granger Cause TGEGDP & 34 & 2.08430 & 0.1426 \\
\hline M2GDP does not Granger Cause INF & & 0.92427 & 0.4082 \\
INF does not Granger Cause M2GDP & 34 & 1.01741 & 0.3741 \\
\hline TGEGDP does not Granger Cause INF & & 1.18229 & 0.3209 \\
INF does not Granger Cause TGEGDP & 34 & 0.27332 & 0.7628 \\
\hline TGEGDP does not Granger Cause M2GDP & & 0.88944 & 0.4218 \\
M2GDP does not Granger Cause TGEGDP & & 0.19367 & 0.8250 \\
\hline
\end{tabular}

Source: Researchers' compilation from E-view 9

\section{Discussion of Results \\ Unit Root Test}

Unit root test result of both Augmented Dickey fuller (ADF) and Philip Perron (PP) indicated that the variables unemployment, inflation, money supply and total government expenditure are not stationary at level but became stationary at $1^{\text {st }}$ difference. This is said to be integrated of the same order 1 (1)

\section{Co-integration Test}

The result of the Johansen co-integration test conducted showed that there is one (1) co- integrating vector which indicated that long-run equilibrium relationship exist between the dependent variable and the independent variables. This can be seen by the trace statistics that its value is greater than $5 \%$ critical value [i.e $(57.72347>$ 47.85613) ] and P-value of 0.0045

\section{Vector Error Correction Model}

The result of the error correction mechanism met the required condition of being negative, fractional and statistically significant. The coefficient of ECM (-1) is - 0.734766 and the P-value $(0.0002)$ therefore the negative sign of the coefficient satisfied one condition and the fact that the P-value is less than the critical value of 0.05 satisfied the second condition statistical significance.

The value of computed multiple determination $\left(\mathrm{R}^{2}\right)$ is 0.531455 showing that $53.1 \%$ of the total variation in unemployment is accounted for, by the explanatory variables: inflation money supply (M2GDP) total government expenditure \% GDP (TGEXGDP) and the remaining $47.9 \%$ in unemployment is attributed to the influence of other factors not included in the regression equation. Durbin Watson statistics is 2.058551 showing the absences of auto correlation among the residuals.

Causality Test

The pairwise Granger causality result in table 8 above indicated that there is unidirectional causality running from TGEXGDP to UNEM with F-statistic value of 3.83090 and corresponding P-value of 0.0334 .

\section{IMPLICATION OF THE RESULTS}

Johansson co integrating test indicated the presence of one co integrating vector proving that there exist long run relationships among the variables. The nature of long run relationship in the equation are seen in normalized cointegrating coefficients and the upper chamber of the VECM as stated below:

$\mathrm{UNEM}=-23.9+0.242103 \mathrm{INF}+0.280614 \mathrm{M} 2 \mathrm{GDP}+0.001015 \mathrm{TGEXGDP}$

The estimated coefficient of the variables, INF, M2GDP, and TGEXGDP bore positive sign indicating long run positive relationship with UNEM. The result conformed to work done by Orji, Anthony-Orji and Okafor (2015) which reported a positive long run relationship between unemployment and inflation. The variable INF did not meet the appriori expectation in the long run as it is expected based on the theory of Philip curve that there exists an inverse relationship among the variables. Also in the short-run, INF had positive significant relationship with unemployment at lag 2, showing disagreement with appriori expectation of the theory of Philip curve. This means that as inflation is increasing, unemployment is also increasing leading to fall in the economic growth (stagflation). TGEXGDP had a positive and significant relationship with unemployment both in the short and long run, while M2GDP exhibited a positive significant relationship with unemployment in the long run but insignificant influence in the short run. This implies that increase in government expenditure reduces unemployment, it can also be inferred from the result that government spending creates employment to the extent that inflation remains within the single digit limit. The result of the causality test showed a unidirectional causality which runs from TGEXGDP to UNEM. The implication is that if government would embark on the policy that could increase total government expenditure, it would lead to reduction on 
unemployment in Nigeria.

\section{SUMMARY OF FINDINGS}

This research work investigated to understand the causal relationship between unemployment and inflation in Nigeria from 1980-2015. The model was specified as unemployment as a function inflation, money supply $\%$ GDP, total government expenditure \% of GDP. The following method and statistical test were used causality test, VECM test, co integration test and the unit root test. Based on the above test carried out study find out that:

(i) Inflation significantly impact unemployment in Nigeria both in the long - run and short - run within the period under review.

(ii) There is significant causal relationship existing among the variables in Nigeria.

R-squared is 0.531455 indicating that $53.1 \%$ change in the dependent variables are explained by the explanatory variables in the model while $47.9 \%$ is accounted for by the variables outside the model.

F-statistics of 2.898686 is significance and Durbin Watson of 2.058551 showed the absence of autocorrelation.

\section{RECOMMENDATIONS}

In regard to the findings above the study recommends that government should use discretionary policy that would reduce unemployment by boosting government expenditure and maintaining stability in money supply as it had a positive impact on unemployment in the long run.

\section{CONCLUSION}

This research work investigated to understand the causal relationship between unemployment and inflation in Nigeria from 1980-2015. The model was specified as unemployment as a function inflation, money supply $\%$ GDP, total government expenditure \% of GDP. The following method and statistical test were used causality test, VECM test, co integration test and the unit root test. Based on the above test carried out study find out that:

(i) Inflation significantly impact unemployment in Nigeria both in the long - run and short - run within the period under review.

(ii) There is significant causal relationship existing among the variables in Nigeria. And in regard to the findings above the study recommends that government should use discretionary policy that would reduce unemployment by boosting government expenditure and maintaining stability in money supply as it had a positive impact on unemployment in the long run.

\section{REFERENCES}

Ademola, A. S. and Badiru, A. (2016) The impact of unemployment and inflation on economic growth in Nigeria, International Journal of Business and Economic Sciences Applied Research 9(1): 47-55.

Al-Zeaud, H. A.(2014) The trade-off between unemployment and inflation evidence from causality test for Jordan, International Journal of Humanities and Social Science 4 (4) Special Issue -February 2014

Arnold R.A. (2004) Macroeconomics, Lachina Publisging service,INC.

Eze, T. C., Apeh, A. S.\& Eze, B. I. (2015) Analysis of the relative impact of inflation and unemployment on nigerian economy: Developing Country Studies 5(17), 201572.

Mohammed, Y., Okoroafor O.K.D.\& Awe, E. O.(2015) Analysis of the relationship between inflation, unemployment and economic growth in Nigeria: Applied Economics and Finance 2(3)102.

Muhammad, S.(2014) Effect of inflation and unemployment on economic growth in Pakistan. Journal of Economics and Sustainable Development 5(15) 2014.

Omoke, P. C. (2010) Inflation and economic growth in Nigeria: Journal of Sustainable Development 3 (2) 159.

Orji, A., Anthony-Orj, O. I \& Okafor J. C. (2015) Inflation and unemployment nexus in Nigeria: another test of the Phillip's curve, Asian Economic and Financial Review, 5(5):766-778

Ugwuanyi C. U. (2004) Intermediate macroeconomics theory, Great AP Express Publishers ltd.

UMARU and ZUBAIRU (2012) An empirical analysis of the relationship between unemployment and inflation in Nigeria Economics and Finance ReviewVol. 1(12) 42-61.

Torruam, J. T. and Abur, C. C. (2014) The relationship between unemployment, inflation and crime: an application of cointegration and causality analysis in Nigeria. Journal of Economics and Sustainable Development 5(4)131. 